\title{
FOREWORD TO THE 2018 \\ ANNIVERSARY EDITION
}

Stephen M. Walt

BY ANY criteria, Kenneth N. Waltz's Man, the State, and War: A Theoretical Analysis merits the label of a classic. Originally written as Waltz's doctoral dissertation at Columbia University in 1954 and subsequently published in I959, Man, the State, and War was soon recognized as a foundational work in the field of international politics. It has been assigned to thousands of college students and continues to be read, pondered, and widely cited more than sixty years later. ${ }^{1}$ The book's iconic status was perhaps best confirmed by the late Stanley Hoffmann of Harvard, who once wrote that if he were asked to assign three books on international relations to a recluse on a desert island, he would choose Thucydides's The Peloponnesian War, Hoffmann's mentor Raymond Aron's Peace and War, and Man, the State, and War. ${ }^{2}$

But what gives Man, the State, and War its special status? Certainly one key feature is its longevity: it has stood the test of time and still offers useful insights decades after it was first published. A second virtue is its depth and subtlety: like all classics, one can return to it over and over and find new wisdoms each time.

Yet the chief contribution of Man, the State, and War is its organization and clarification of a large, disparate, and frequently contradictory body of Western thought that

I. As of this writing, Man, the State, and War has nearly 6,000 Google Scholar citations, putting it far ahead of many more recent works.

2. See Stanley Hoffmann, "An American Social Science: International Relations," Daedalus, I06, no. 3 (Summer 1977), 5 I. 
attempted to explain the causes of war and tell us how we might make the world more peaceful. Waltz shows that these different theories can be grouped into three distinct categories, which he calls "images." The first image emphasizes the nature of human beings, while the second image stresses the internal structure of the states that comprise the international system. The third image focuses on the structure or architecture of that system. Within each image, Waltz identifies striking similarities between the writings of classical political theorists, modern social scientists, and politicians and reformers of various stripes. This keen insight into how to organize the field-which Waltz later recalled as a "light [that] flashed in my mind"-gives readers a simple but powerful framework for classifying and weighing competing arguments about the origins of war. ${ }^{3}$

But Man, the State, and War does more than just sort the existing literature; Waltz also has important things to say about the strengths and weaknesses of the arguments contained in each image. He appreciates the wisdom offered in the diverse writings that he examines, but he is also keenly aware of their limitations. His critiques of different works are acute and compelling; in each case, Waltz cuts to the core of a thinker's arguments and shows us where they stand and where they fall.

Most importantly, he emphasizes that wars are caused by factors found within each image, while the absence of a central political authority in the international systemwhat is commonly called anarchy-both makes war possible and impels states to compete with one another whether they wish to or not. For this reason, remedies located within a particular image are doomed to fail. Thus, Man, the State,

3. Kenneth N. Waltz, "Preface to the $200 \mathrm{r}$ edition," Man, the State, and War: A Theoretical Analysis (New York: Columbia University Press, 200I), viii. 
and War doesn't just classify the existing literature, it teaches us how to think critically about the contents of each image and about how those images relate to each other.

As Waltz later acknowledged, he did not put forth a theory of international politics in Man, the State, and War. He accomplished that task two decades later in another landmark book. ${ }^{4}$ But Man, the State, and War does contain several key ideas that Waltz drew upon in that later work, and it underscores the importance he places on theory as the essential ingredient for human understanding. As he writes in the introduction, "The empirical approach, though necessary, is not sufficient. The correlation of events means nothing, or at least should not be taken to mean anything, apart from the analysis that accompanies it." At the very start of his long and distinguished career, Waltz had grasped that theories are the indispensable link between observation and understanding. Without theory to guide us, piling up empirical associations is at best pointless and at worst leads us astray.

Finally, Man, the State, and War is a classic because it is a pleasure to read, a quality that has become increasingly rare in scholarly writings about international affairs. In addition to his other virtues, Waltz was a graceful and witty writer who drew easily upon literature, philosophy, history, and economics to enliven, inform, and entertain his readers. Waltz's erudition and command of his materials cannot fail to impress: it is clear he has read widely and thought deeply, and therefore it is unsurprising that his commentaries on thinkers ranging from Spinoza to Kant, from Wilson to Lenin, or from Morgenthau to Machiavelli (and many more) are an education in themselves. 
Waltz does not dumb down his discussion for his readers' sake, or try to sound profound by employing obscure language. His writing style is sophisticated but accessible, even when he is addressing complex arguments and concepts that are difficult to grasp. This quality makes Man, the State, and War an ideal book to assign to students: it helps them think clearly about international politics without making the process harder than necessary. Indeed, it makes learning about the causes of war enjoyable.

I first encountered this book in the fall of 1975 . It was required reading in my introductory international relations course at college, and it was one of the first scholarly books on international relations that I ever read. The experience was both exhilarating and illuminating: I suddenly felt that I understood the problem of war in ways I had never considered before. I still had vast amounts to learn, of course, but reading Man, the State, and War helped convince me that it was possible to make sense of something as pervasive, enduring, and terrible as human conflict, and perhaps even draw a bit closer to solving it. Reading the book also made me curious about its author, and played no small role in my decision to study with him in graduate school.

Classic works of scholarship are rare, no matter how hard scholars try to produce them. Writing a seminal book requires asking big questions and providing bold and innovative answers, something that is much easier said than done. Rereading Man, the State, and War some forty years after I first encountered it reaffirms my deep respect for its author and his achievement, as well as my gratitude that I discovered it when I did. If you are about to read it for the first time, I hope you experience the same sense of discovery and appreciation. 